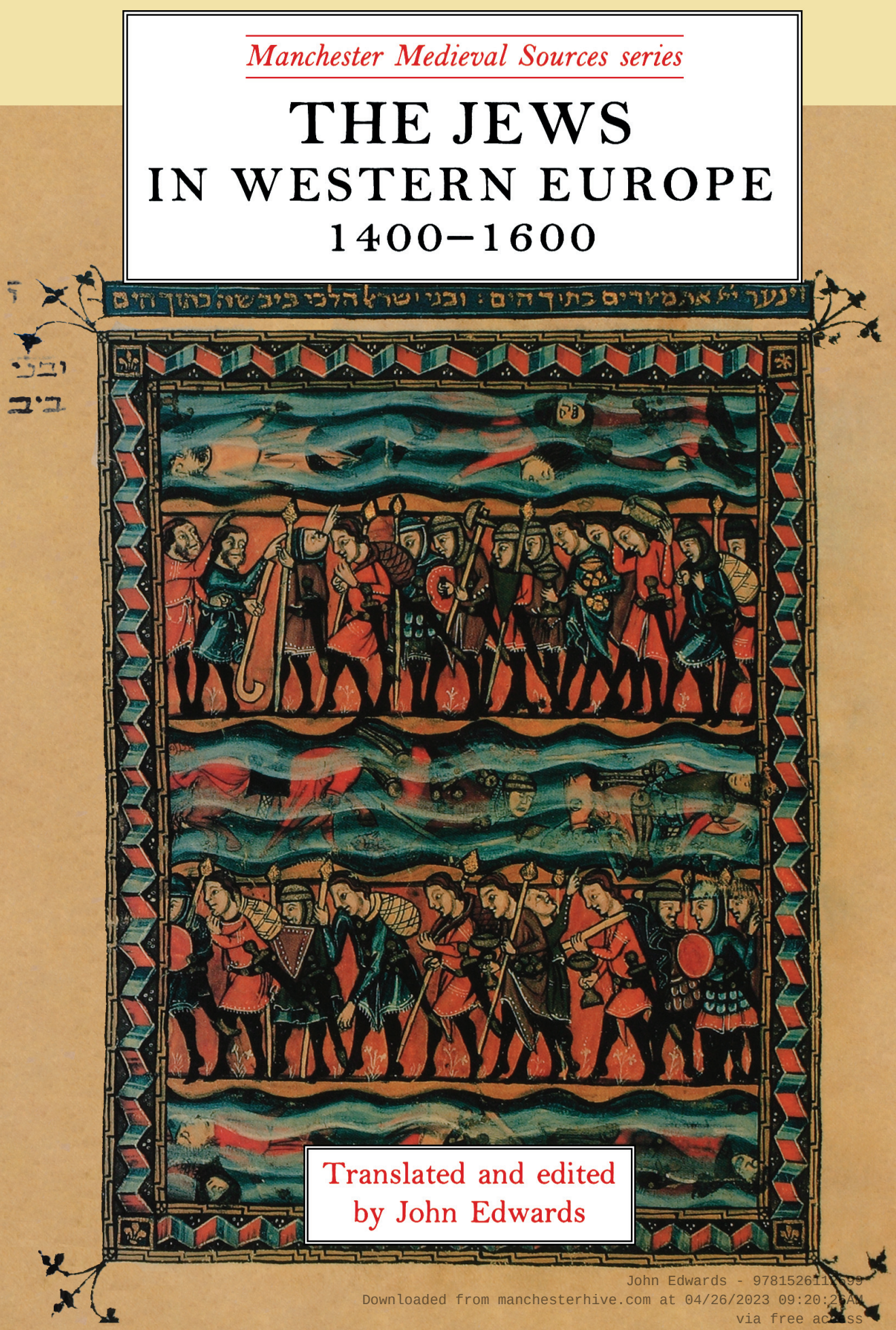




\section{THE JEWS IN WESTERN EUROPE 1400-1600}

As European politics, society, economy and religion underwent epoch-making changes between 1400 and 1600 , the treatment of Europe's Jews by the nonJewish majority was, then as in later periods, a symptom of social problems and tensions in the Continent as a whole.

Through a broad-ranging collection of documents, John Edwards sets out to present a vivid picture of the Jewish presence in European life during this vital and turbulent period. Subjects covered include the Jews' own economic presence and culture, social relations between Jews and Christians, and the policies and actions of Christian authorities in Church and State. He also draws upon original source material to convey ordinary people's prejudices about Jews, including myths about Jewish 'devilishness', moneygrabbing, and 'ritual murder' of Christian children.

Full introductory and explanatory material makes accessible the historical context of the subject and highlights the insights offered by the documents as well as the pitfalls to be avoided in this area of historical enquiry. 
Manchester Medieval Sources series

series adviser Janet L. Nelson

This series aims to meet a growing need amongst students and teachers of medieval history for translations of key sources that are directly usable in students' own work. The series will provide texts central to medieval studies courses and will focus upon the diverse cultural, social as well as political conditions that affected the functioning of all levels of medieval society. The basic premise of the new series is that translations must be accompanied by sufficient introductory and explanatory material and each volume will therefore include a comprehensive guide to the sources' interpretation, including discussion of critical linguistic problems and an assessment of the most recent research on the topics being covered.

already published in the series

Janet L. Nelson The Annals of St-Bertin: ninth-century histories, volume I

Timothy Reuter The Annals of Fulda: ninth-century histories, volume II

Chris Given-Wilson Chronicles of the Revolution, 1397-1400: the reign of Richard II

R. N. Swanson Catholic England: faith, religion and observance before the Reformation

Rosemary Horrox The Black Death

forthcoming titles in the series will include

Donald Bullough The Vikings in Paris

Simon Lloyd The impact of the crusades: the experience of England, 1095-1274

Richard Smith Sources for the population history of England, 1000-1540

J. A. Watt The origins of anti-semitism in Europe

Alison McHardy The early reign of Richard II

Ian Robinson The pontificate of Gregory VII

Edward Powell Crime, law and society in late medieval England

Jeremy Goldberg Women in England 


\section{THE JEWS \\ IN WESTERN EUROPE \\ 1400-1600}

translated and edited by John Edwards

Manchester University Press

Manchester 
Copyright (C) John Edwards 1994

The right of John Edwards to be identified as the author of this work has been asserted by him in accordance with the Copyright, Designs and Patents Act 1988.

Published by Manchester University Press

Altrincham Street, Manchester Mi 7JA

www.manchesteruniversitypress.co.uk

British Library Cataloguing-in-Publication Data

A catalogue record for this book is available from the British Library

Library of Congress cataloging in publication data

A catalogue record for this book is available from the Library of Congress

ISBN 978 o 719035098 paperback

First published by Manchester University Press 1994

The publisher has no responsibility for the persistence or accuracy of URLs for any external or third-party internet websites referred to in this book, and does not guarantee that any content on such websites is, or will remain, accurate or appropriate.

Typeset in Monotype Bell

by Koinonia Ltd, Manchester 